\title{
Sucho v povodí horní Metuje v letech 2014-2019
}

\section{Drought in the Upper Metuje Basin in 2014-2019}

\author{
JAN KAŠPÁREK \\ Klíčová slova: hydrologické sucho - hydrologická bilance - \\ polická křídová pánev
}

\author{
JAN KAŠPÁREK \\ Key words: hydrological drought - hydrological balance - \\ Police Cretaceous basin
}

\section{SOUHRN}

V letech 2014-2019 bylo na území České republiky historické sucho. Oddělení hydrologie a hydrogeologie Výzkumného ústavu vodohospodářského T. G. Masaryka provádí dlouhodobá hydrologická a hydrogeologická pozorování v povodí horní Metuje, kde se toto sucho výrazně projevilo. Horní část povodí řeky Metuje se nachází v geologickém útvaru polická křídová pánev (dále jen polická pánev). Díky málo propustnému podloží a velké mocnosti křídových pískovců je zde velká zásoba kvalitní podzemní vody, která je odebírána pro vodárenské zásobování mnoha obcí a měst ve východních Čechách. Sledované povodí je uzavřeno vodoměrnou stanicí na řece Metuji, ve městě Teplice nad Metují (M XII). Stanice je umístěna na vodním toku v malé vzdálenosti pod skalským zlomem. Struktura skalského zlomu je pro proudění podzemní vody nepropustná a zlom prríčně protíná celý rozsah polické pánve. Na skalském zlomu a nad ním jsou vydatné prameny a je zde prímá dotace podzemní vodou do řeky, takže k profilu vodoměrné stanice je povodí pro hydrologickou bilanci uzavřené. Tato uzavřenost povodí umožňuje relativně přesné rozdělení vody srážkové na výpar, povrchový odtok a podzemní odtok. Ve středu povodí horní Metuje je provozována meteorologická stanice Bučnice, dále tu probíhá měření hladiny podzemní vody hlubokých kolektorů a mělkého kolektoru pozorovacími vrty a pozorování doplňkových vodoměrných stanic na Metuji a na Zdoňovském potoce.

Pro rozbor problému sucha byla rešena hydrologická bilance povodí. Dostupná data od roku 1970 do roku 2019 byla zkontrolována, zpřesněna a zpracována modelem Bilan. Vstupy modelu jsou řady atmosférických srážek (P) a teplot vzduchu (T). Parametry modelu jsou kalibrovány na shodu průběhu celkového měřeného odtoku z povodí (R) a modelovaného odtoku (RM). Výstupem modelu je modelovaný odtok z povodí (RM), výpar (ET), dotace podzemní vody a základní odtok (BF). Bilan dále počítá potenciální evapotranspiraci (PET) a zásobu podzemní vody (GS).

Teplota vzduchu měřená na klimatické stanici Bučnice má za dobu pozorování trvalý stoupající trend $0,04^{\circ} \mathrm{C} /$ rok. Ke zjištění podílu tohoto oteplování na suchém období 2014-2019 a také k určení celkového vlivu na odtok z povodí byly programem Bilan modelovány hydrologické poměry v povodí i pro variantu bez tohoto oteplování.

Výsledkem bylo zjištění primární prríčiny sucha - tou byl pokles atmosférických srážek oproti průměru o 8,6 mm/měsíc a odpovídající pokles odtoku. $\checkmark$ modelové variantě bez dlouhodobého oteplení byl nižší výpar o $4 \mathrm{~mm} / \mathrm{měsíc}$ a o tuto hodnotu by byl menší také pokles odtoku. $V$ celkové hydrologické bilanci má dlouhodobé oteplování vzduchu přímý vliv na růst výparu, jehož následkem je pokles celkového i základního odtoku. Dlouhodobý pokles odtoku na závěrném profilu M XII má trend $2 \mathrm{l} / \mathrm{s} /$ rok.

\section{ABSTRACT}

In the years 2014-2019, there was a historic drought in the Czech Republic. The Department of Hydrology and Hydrogeology of the T. G. Masaryk Water Research Institute has been carrying out long-term hydrological and hydrogeological observations in the upper Metuje basin where this drought manifested itself significantly. The upper part of the catchment area of the Metuje River is located in the Police Cretaceous basin geological formation. Due to subsoil with low permeability and great thickness of Cretaceous sandstones, there is a large storage of quality groundwater, which is used for water supply to numerous municipalities and towns in Eastern Bohemia. The monitored catchment area is closed by a water gauging station on the Metuje River in the town of Teplice nad Metuji (M XII). The station is located on the river in a small distance below the Skalský fault. The structure of the Skalský fault is impermeable to groundwater flow and the fault transversely intersects the whole Police basin. There are abundant springs above and at the Skalský fault and groundwater is directly recharged into the river there. Up to the profile of the water gauging station the river basin is thus hydrologically closed. This feature of the catchment area allows a relatively precise division of precipitation into evaporation, surface runoff and groundwater runoff. The Bučnice meteorological station is operated in the centre of the upper Metuje basin. Groundwater levels of deep aquifers and one shallow aquifer are measured by observation wells there. Additional water gauging stations operate on the Metuje River and on the Zdoňovský Creek.

To analyse the issue of drought, hydrological balance of the river basin was used. Available data from 1970 to 2019 were checked, specified and used as an input into the Bilan model. The input into the model consisted of series of atmospheric precipitation $(P)$ and air temperatures $(T)$. Parameters of the model were calibrated to match the values of series of total measured runoff (R) and modelled runoff (RM). Outputs of the model include modelled runoff from the river basin, evaporation (ET), groundwater recharge and base flow (BF). The Bilan model also calculates potential evapotranspiration (PET) and groundwater storage (GS).

Air temperature measured at the Bučnice meteorological station has a continuous upward trend over the observation period (a gradient of $0.04^{\circ} \mathrm{C} /$ year). In order to determine the contribution of warming to the drought of 2014-2019 and its overall impact on runoff from the basin, hydrological conditions in the basin have been modelled by the Bilan programme also for a variant without this warming.

This has resulted in determining the primary cause of the drought, namely a decrease in atmospheric precipitation by $8.6 \mathrm{~mm} / \mathrm{month}$ in comparison with the average, and a corresponding decrease in runoff. In the modelled variant 


\section{ÚVOD}

V letech 2014-2019 zasáhlo území střední Evropy historické sucho. Bezprostřední prríčinou sucha byly opakující se dlouhodobé nezvyklé cirkulační podmínky, které bránily postupu frontálních systémů do střední Evropy. Zda je tato změna proudění ojedinělou anomálií, periodou pravidelného cyklu, nebo následkem změn klimatu, bude možné věrohodně posoudit až zpětně. $V$ tomto príspěvku bude upřesněn podíl dvou hlavních příčin sucha - nižších atmosférických srážek a zvýšené teploty vzduchu.

VúV TGM provádí dlouhodobá a nepřetržitá pozorování klimatických, hydrologických a hydrogeologických parametrů v povodí horní Metuje, data získaná z těchto pozorování byla použita k analýze problematiky sucha v daném regionu.

\section{HYDROGEOLOGICKÉ POMĚRY POVODÍ HORNÍ METUJE}

Schematická situace horního povodí Metuje je na obr. 1. Sledované území je povodí horní Metuje po polohu vodoměrné stanice označované M XII na jižním okraji města Teplice nad Metují. Toto povodí leží v horní části polické pánve, která je tvořena geologickými útvary křídy a triasu. Plošná rozloha polické pánve je větší než morfologická plocha povodí Metuje. Druhým významným tokem je na severozápadě Dřevíč.

Křídové a triasové sedimenty velké mocnosti ( $v$ centrální části přes $500 \mathrm{~m}$ ) leží na permo-karbonské vnitrosudetské (dolnoslezské) pánvi. Toto málo propustné podloží spolu s brachysynklinální (miskovitě prohnutou) polohou uložení pánve umožňuje akumulaci velkého objemu podzemní vody v křídovém a triasovém útvaru. Krásný [6] oblast horního povodí Metuje po skalský zlom popisuje jako „severní zvodněný systém“ polické pánve se samostatným oběhem podzemních vod.

Atmosférické srážky dotují zásobu podzemní vody v celé ploše pánve [1]. Proudění podzemní vody po překonání provzdušněného horninového prostředí (zóna aerace) je dále komplikované. Propustnost jednotlivých vrstev sedimentů je rozdílná, jsou zde ověřeny dobře propustné vrstvy a vrstvy izolační. Těleso křídového útvaru je tektonicky značně rozrušeno a tyto poruchy a pukliny mohou být podle druhu výplně propustné, nebo izolační. Hynie [2] uvádí možný izolační vliv ve vyšší poloze a drenážní v hloubce i na struktuře jedné poruchy. Také Ize z brachysynklinálního prohnutí pánve předpokládat poruchy k povrchu převážně stlačené a k podloží rozevřené.

$\checkmark$ tomto prostorově členitém prostředí lze definovat dva významné samostatné kolektory - kolektor kvádrových pískovců D a kolektor pískovců cenomanu A. Méně významný je kolektor ve vrstvách turonu (C), významný izolátor jsou slínovce spodního turonu.

$\checkmark$ cenomanských pískovcích, které jsou částečně překryty sedimenty turonu, je kolektor A. Ten se dále dělí na výše položený kolektor A2 (rohovcové vrstvy) a na u báze křídového útvaru ležící kolektor A1, jenž je spojitý s podložním kolektorem triasu T. Tento spodní kolektor A1/T má velmi dobrou propustnost a odvádí většinu, možná všechnu podzemní vodu z kolektoru A k vývěrům v Teplicích, nad a u skalského zlomu (tzv. teplický výronový okrsek). Skalský zlom je pro proudění podzemní vody nepropustný, vzdouvá její hladinu a rozděluje polickou pánev na dva hydrogeologicky takřka samostatné celky.

V kvádrových pískovcích Adršpašsko-teplických skal (coniacko-teplické souvrství) se nachází prostorově členitá zvodeň kolektoru D. Tento kolektor je od níže položeného kolektoru C izolován málo propustnými slínovci, a tak podzemní voda odtéká četnými prameny na erozní úrovni toků, které se do této slínovcové vrstvy zahloubily. Ve skalních městech je mnoho drobných pramenů, na severovýchodním okraji skal jsou v údolí Metuje čtyři vydatné prameny. Jižní oblast skalního města je odvodňována do Skalního potoka, vydatnější prameny odvádějící vodu k Metuji tu nejsou. without long-term warming, evaporation and the decrease in runoff would both have been by $4 \mathrm{~mm} / \mathrm{month}$ lower. In the overall hydrological balance, the long-term air temperature increase has a direct impact on a rise in evaporation, which results in a decline in total runoff as well as base flow. Runoff at the M XII outlet of the basin has a long-term declining trend of $2 \mathrm{l} / \mathrm{s} /$ year.

\section{INTRODUCTION}

In 2014-2019 Central Europe was hit by a historic drought. The immediate cause of the drought was repeated long-term unusual circulation conditions that prevented frontal systems to move to Central Europe. It will be possible only in retrospect to make a credible assessment about whether this change in flow is a one-off anomaly, a period within a regular cycle or the result of climate change. This paper specifies the contribution of two main causes of draught, namely lower atmospheric precipitation and increased air temperature.

The T. G. Masaryk Water Research Institute has been carrying out long-term continuous observations of climatological, hydrological and hydrogeological parameters in the upper Metuje basin. Data obtained from these observations have been used to analyse the issue of drought in the region.

\section{HYDROGEOLOGICAL CONDITIONS IN THE UPPER METUJE BASIN}

Fig. 1 shows a schematic situation of the upper Metuje basin. The monitored area comprises the upper Metuje basin up to the location of a water gauging station marked M XII on the Southern outskirts of the town of Teplice nad Metují. This catchment area lies in the upper part of the Police basin, which is made of Cretaceous and Triassic geological formations. The Police basin is larger than the morphological area of the Metuje basin. A second significant watercourse is the Dřevič Creek in the North-West.

Cretaceous and Triassic sediments of great thickness (exceeding $500 \mathrm{~m}$ in the central part) lie on the Permian-Carboniferous inner-Sudetenland (LowerSilesian) basin. This subsoil that has low permeability and the brachysyncline (dish-shaped) placement of the basin allows accumulation of a large volume of groundwater in the Cretaceous and Triassic formation. Krásný [6] describes the upper Metuje basin up to the Skalský fault as a "Northern aquiferous system" of the Police basin with an independent groundwater circulation.

Atmospheric precipitation recharges groundwater storage in the whole area of the basin [1].

After groundwater overcomes the aerated rock environment (the aeration zone), its further flow is complicated. The permeability of individual sediment layers differs since both layers with good permeability and isolating ones have been established here. The body of the Cretaceous formation has been tectonically considerably eroded and these faults and joints can be permeable or isolating depending on the type of filling. Hynie [2] mentions a potential isolating effect in upper locations and a drainage effect in the depth even in the structure of a single fault. It may also be assumed from the brachysyncline curvature of the basin that faults near the surface are predominantly compressed and faults near the subsoil are open.

Two important individual aquifers may be designated in this varied environment, an aquifer of cuboid-shaped sandstones (D) and an aquifer of Cenomanian sandstones (A). There is an aquifer of minor importance in the Turonian layers (C) since marlite of the Lower Turonian acts as a significant isolator.

Aquifer $\mathrm{A}$ is located in Cenomanian sandstones that are partially covered by Turonian sediments. This aquifer is divided into aquifer A2 (chert layers) located higher and aquifer A1 situated at the base of the Cretaceous formation and connected with the Triassic subsoil aquifer $(T)$. The A1/T lower aquifer has very 
Tab. 1. Skladba odtoku a specifické odtoky dílčich částí povodí Metuje

\begin{tabular}{|c|c|c|c|c|}
\hline Vodní tok/pramen & $\begin{array}{l}\text { Průměrné spec. odtoky } \\
\text { a vydatnosti }\left[1 . s^{-1}\right]\end{array}$ & $\begin{array}{l}\text { Poměr k odtoku } \\
\text { v profilu M XII [\%] }\end{array}$ & Kolektor & $\begin{array}{l}\text { Průměrný specifický } \\
\text { odtok }\left[1 . \mathrm{s}^{-1} \cdot \mathrm{km}^{-2}\right]\end{array}$ \\
\hline Metuje ze skal & 53 & 6,4 & DC & 8,5 \\
\hline Adršpašský potok & 80 & 9,7 & C & 7 \\
\hline Mořské oko & $\underline{8}$ & 1,0 & D & \\
\hline Jezírko & 4 & 0,5 & $\mathrm{D}$ & \\
\hline Metuje nad Zdoňovským potokem & $\underline{145}$ & 17,6 & & 7,3 \\
\hline Zdoňovský potok & 150 & 18,2 & $C D$ & 6,7 \\
\hline Metuje M VII & $\underline{295}$ & 35,8 & & 7 \\
\hline Prameny Spálený mlýn & 22 & 2,7 & D & \\
\hline Bučnice & 26 & 3,2 & $C D$ & 6,5 \\
\hline Metuje M VIII & $\underline{376}$ & 45,6 & & 7,9 \\
\hline Pramen Bučnice & 2 & 0,2 & $\mathrm{D}$ & \\
\hline Pramen Děd & 5 & 0,6 & $\mathrm{D}$ & \\
\hline Pramen u kempu & 1 & 0,1 & $\mathrm{D}$ & \\
\hline Výronový úsek po Orlík & 55 & 6,7 & Pozn. 1. & \\
\hline Skalní potok & 80 & 9,7 & $D$ & 11 \\
\hline Pramen odtok vodárna & 1 & 0,1 & $\mathrm{D}$ & \\
\hline Pramen Antoníček & 5 & 0,6 & A ? & \\
\hline Hornoteplický potok & 37 & 4,5 & C & 6 \\
\hline TVO a odběr & 215 & 26,1 & $A$ & \\
\hline Skalský potok & 12 & 1,5 & $\mathrm{D}$ & \\
\hline Bohdašínský potok & 36 & 4,4 & C & 5,5 \\
\hline Metuje M XII & 825 & 100,0 & & 11 \\
\hline
\end{tabular}

Poznámky k tab. 1. Uvedené průtoky a vydatnosti reprezentuji prüměrné hodnoty, v suchých obdobích prưtoky Adršpašského, Zdoňovského, Hornoteplického a Bohdašínského potoka klesají knule. Hodnoty podtrženéjsou měrené, uvedené normálním řezem písma dopočítané, kurzívou odvozené.

Pozn. 1. Výronový úsek do Metuje od profilu M VIII po Orlík nelze jednoznačně prirăadit kjedinému kolektoru.

Z mnoha podélných měření průtoků a vydatnosti pramenů byla zjištěna skladba průměrných průtoků a odtoků podzemní vody do Metuje (tab. 1). Plošné rozložení dotace podzemních vod srážkami lze posoudit podle specifických odtoků. Jejich porovnání pro dílčí oblasti povodí je uvedeno také v tab. 1.

\section{OVLIVNĚNÍ PŘIROZENÝCH HYDROGEOLOGICKÝCH POMĚRŮ V POVODÍ HORNÍ METUJE}

Zásoba podzemní vody v polické pánvi, resp. možnost jejího využití pro vodárenské zásobování pitnou vodou, byla zkoumána od poloviny 20. století. Ota Hynie prováděl rozsáhlý počáteční průzkum, dále $v$ průzkumu pokračoval národní podnik Vodní zdroje, práce vedl geolog Vojtěch Kněžek. good permeability and drains away most, possibly all, groundwater from aquifer A to outflows in Teplice above and at the Skalský fault (known as the Teplice outflow zone). The Skalský fault is impermeable to groundwater flow, raising its level and dividing the Police basin into two nearly separate units from the hydrogeological perspective.

A spatially varied aquifer $D$ is located in cuboid-shaped sandstones of the Adršpach-Teplice Rocks (the Coniac-Teplice formation). This aquifer is isolated from aquifer $C$, which is located lower, by marlite with low permeability and groundwater thus flows away via multiple springs at erosion level of watercourses that are embedded in this marlite layer. There are numerous minor springs in the rock towns and in the North-Eastern boundary of the rocks there are four abundant springs in the Metuje River valley. The Southern rock town area is drained to the Skalní Creek and there are no abundant springs draining water to the Metuje River. 
Tab. 1. Runoff composition and specific runoffs of sub-parts of the Metuje basin

\begin{tabular}{|c|c|c|c|c|}
\hline Watercourse/spring & $\begin{array}{l}\text { Average specific runoffs } \\
\text { and abundance }\left[\mathrm{I} . \mathrm{s}^{-1}\right]\end{array}$ & $\begin{array}{l}\text { Ratio to runoff in } \\
\text { the } M \text { XII profile [\%] }\end{array}$ & Aquifer & $\begin{array}{l}\text { Average specific } \\
\text { runoff }\left[1 . \mathrm{s}^{-1} \cdot \mathrm{km}^{-2}\right]\end{array}$ \\
\hline Metuje from the rocks & 53 & 6.4 & DC & 8.5 \\
\hline Adršpašský Creek & 80 & 9.7 & C & 7 \\
\hline Mořské oko spring & $\underline{8}$ & 1.0 & D & \\
\hline Jezírko spring & 4 & 0.5 & $\mathrm{D}$ & \\
\hline Metuje above the Zdoňovský Creek & $\underline{145}$ & 17.6 & & 7.3 \\
\hline Zdoňovský Creek & 150 & 18.2 & $C D$ & 6.7 \\
\hline Metuje M VII & $\underline{295}$ & 35.8 & & 7 \\
\hline Spálený mlýn springs & 22 & 2.7 & D & \\
\hline Bučnice Creek & 26 & 3.2 & $C D$ & 6.5 \\
\hline Metuje M VIII & $\underline{376}$ & 45.6 & & 7.9 \\
\hline Bučnice spring & 2 & 0.2 & $\mathrm{D}$ & \\
\hline Děd spring & 5 & 0.6 & $\mathrm{D}$ & \\
\hline Spring at the campsite & 1 & 0.1 & D & \\
\hline Outflow zone up to Orlík & 55 & 6.7 & Note No. 1. & \\
\hline Skalní Creek & 80 & 9.7 & $D$ & 11 \\
\hline Spring/Outlet at a water company & 1 & 0.1 & $\mathrm{D}$ & \\
\hline Antoníček spring & 5 & 0.6 & A? & \\
\hline Hornoteplický Creek & 37 & 4.5 & C & 6 \\
\hline Teplice outflow zone and water supply & 215 & 26.1 & $A$ & \\
\hline Skalský Creek & 12 & 1.5 & $\mathrm{D}$ & \\
\hline Bohdašínský Creek & 36 & 4.4 & C & 5.5 \\
\hline Metuje M XII & $\underline{825}$ & 100.0 & & 11 \\
\hline
\end{tabular}

Notes to Tab. 1. The given discharge and abundance values represent averagevalues. In periods of drought the discharge of Adršpašský, Zdoňovský, Hornoteplický and Bohdašinský Creeks drop to zero. Underlined values are measured, those in Roman font are calculated and those in Italic are derived.

Note No. 1. The outflow section to the Metuje River from the M VIII profile up to Orlik cannot be clearly assigned to a single aquifer.

Od konce 60. let jsou v povodí horní Metuje v teplickém výronovém okrsku vodárenské odběry podzemní vody a její odvedení mimo povodí. Jako první byl jímán pramen Sokol k zásobování obce Meziměstí (cca 1968-2003). Od začátku 90. let je podzemní voda čerpána z hlubokých vrtů (VS-5 a VS-15) v blízkosti pramene Rybárna k zásobování větší oblasti napojené na Východočeskou vodárenskou soustavu. Mimo teplický výronový okrsek je čerpán vrt VS-13. Odběrem vody z pramene kromě deficitu průtoku odpovídajícímu odběru k žádnému ovlivnění přirozeného režimu nedošlo. Čerpání podzemní vody z vrtů ovlivňuje proudění a hladinu podzemní vody v pánvi, po zahájení odběrů je patrný pokles hladiny podzemní vody $v$ kolektorech A1T a A2. Předpokládáme, že pokud je zachován prírozený odtok podzemní vody v teplickém výronovém okrsku, k významnějšímu ovlivnění zásoby podzemní vody nedochází.

Lze předpokládat, že přirozené podmínky proudění podzemní vody ovlivňuje také samotná existence mnoha hydrogeologických a jiných vrtů. V pánvi jsou desítky vystrojených vrtů, mnohé nevhodným technickým provedením
Numerous longitudinal measurements of the discharge and abundance of springs established the composition of average discharge and runoff of groundwater to the Metuje River (Tab. 1). Spatial division of groundwater recharge by precipitation may be assessed according to specific runoffs. Their comparison for sub-parts of the basin is also presented in Tab. 1.

\section{IMPACT ON NATURAL HYDROGEOLOGICAL CONDITIONS IN THE UPPER METUJE BASIN}

Groundwater storage in the Police basin and the possibility of its use for drinking water supply has been investigated since the mid-20 $0^{\text {th }}$ century. Ota Hynie carried out an extensive initial exploration, which was followed by a national enterprise Vodní zdroje where the exploration was led by geologist Vojtěch Kněžek. 
propojují kolektory, karotážní měření vertikální proudění podzemní vody vrtem často potvrzují. Staré vrty jsou ve špatném stavu a rozsah propojení kolektorů se u nich $v$ čase mění. Na západním okraji povodí byly v pánvi vrtány hluboké ložiskové vrty (průzkum ložiska uhlí); zda byly likvidovány s ohledem na možné ovlivnění režimu podzemních vod, není známo.

Možnost ovlivnění hladiny podzemní vody v severní části polické pánve mohla nastat také snížením hladiny podzemní vody v důsledku čerpání důlních vod na uhelných dolech. Od hranice kř́lového útvaru 1200 m na západ byl důl Kateřina, podzemní práce tohoto dolu dosahují téměř k podloží kř́idových hornin. Důlní vody zde byly čerpány približně od počátku 20. století do roku 1993, a to z velké hloubky (-460 m n. m.), v množství průměrně 60 I.s.-1. Po zatopení dolu od roku 1996 důlní voda volně odtéká starou štolou v údolí Jívky. Po ukončení čerpání, během zatápění důlních prací ani po zatopení dolu nebyla na chodu a úrovni hladiny podzemní vody v kř́ldové pánvi zaznamenána žádná změna, která by vybočovala z běžného režimního i dlouhodobého chodu. Vliv čerpání a ukončení čerpání důlních vod na hydrogeologické poměry v polické pánvi je zanedbatelný až žádný, a to $v$ souladu s předpokládanou malou propustností permo-karbonského podloží pánve.

\section{POZOROVÁNÍ V POVODÍ HORNÍ METUJE}

VÚV TGM se na průzkumu polické pánve podílí od roku 1964, při řešení mnoha úkolů spolupracuje především s podnikem Vodní zdroje, a. s., Českým hydrometeorologickým ústavem (ČHMÚ) a společností Progeo, s. r. o. Většina zpracovaných úkolů obsahovala řešení bilanční rovnice povodí a zpřesňování jejích složek, a to v povodí horní Metuje, dílčím experimentálním povodí Bučnice [3] a v celé polické pánvi. Souvislé datové řady vyhodnocených hydrologických, hydrogeologických a klimatických pozorování pro povodí horní Metuje jsou k dispozici od roku 1970

Závěrný profil pro měření průtoku-odtoku pro toto povodí je M XII na dolní hranici města Teplice. Profil vodoměrné stanice je betonový jez s propustí, provedením je blízký složenému měrnému přelivu. Př́strojová měření hladiny, měření průtoků hydrometrickou vrtulí a vyhodnocení průtoku zde probíhají souvisle od roku 1970. Plocha povodí Metuje po profil M XII je 74,39 km². Dále jsou v povodí Metuje doplňkové vodoměrné stanice, na Metuji profil M VIII u Skalního mlýna, také pozorovaný od roku 1970, spolu s novějším doplňkovým profilem M VII (2017) pod soutokem se Zdoňovským potokem. Na závěrném profilu Zdoňovského potoka Z VI probíhá pozorování od roku 1996. Měření z těchto stanic upřesňují odtokové poměry jednotlivých částí povodí a také zpřesňují a kontrolují měření na závěrném profilu M XII.

Hladinu podzemní vody sleduje trojice vrtů. Od roku 1972 probíhá měření hladiny ve vrtu VS-3. Úroveň hladiny tohoto vrtu je dána propojením více kolektorů, významný je především vliv zvodně kolektoru rohovcových vrstev A2. Bazální kolektor A1/T je sledován vrtem V-28 od roku 1990. Poměry v kvarterní svrchní zvodni sleduje dvojice blízko sebe položených vrtů V-6 (od roku 1970) a NS, které jsou vyhodnocovány společně. Hladinu podzemní vody v severní části polické pánve sledují také pozorovací objekty ČHMÚ, dostupná data byla k upřesnění odtokových poměrů využita.

Na pozorovací stanici Bučnice probíhá od roku 1970 základní klimatické pozorování, měření atmosférických srážek a teploty vzduchu. Od roku 1999 je zde v provozu automatická meteorologická stanice.

Zjednodušená situace polohy povodí horní Metuje v polické pánvi a umístění pozorovacích objektů je na obr.1.
Since the late 1960s, groundwater in the Teplice outflow zone of the upper Metuje basin has been used for water supply and the taken away from the catchment area. The first spring to be used was the Sokol spring, which supplied the Meziměstí municipality (approximately 1968-2003). Since the early 1990s groundwater has been drawn from deep wells (VS-5 and VS-15) in the vicinity of the Rybárna spring to supply a more extensive area connected to the EasternBohemian water system. Outside the Teplice outflow zone, water is also drawn from the VS-13 well. Besides a flow deficit corresponding with the abstraction, water abstraction from the spring has not had any impact on the natural regime. Drawing of groundwater from the wells has an impact on groundwater flow and level in the basin. After the above abstractions have started, groundwater level in aquifers A1T and A2 has dropped. It may be assumed that as long as natural groundwater runoff is maintained in the Teplice outflow zone, groundwater storage is not significantly affected.

It may be presumed that natural groundwater flow conditions are also influenced by the sheer existence of numerous hydrogeological and other wells. There are dozens of fitted wells in the basin, many of which interconnect aquifers because of their inadequate technical execution. Logging measurements often confirm vertical water flows through the wells. Old wells are in a poor condition and the extent of aquifer interconnection changes over time. Deep exploratory wells were drilled in the Western boundary of the catchment area (for the sake of exploring a coal deposit) and it is not known whether they have been liquidated with a view to a potential impact on the groundwater regime.

Groundwater level in the Northern part of the Police basin could also be influenced by a decrease in groundwater level as a result of abstraction of mining water in coal mines. The Katerina mine was located 1,200 $\mathrm{m}$ to the West of the Cretaceous formation boundary. Groundwork at this mine reached nearly the subsoil of Cretaceous rocks. Mining water was drawn here approximately from the early $20^{\text {th }}$ century until 1993 from a great depth (460 m below sea level) in the average amount of $601 . \mathrm{s}^{-1}$. After the mine was flooded in 1996, mining water has been flowing away freely through an old gallery in the Jívka Creek valley. Changes in groundwater flow and level in the Cretaceous basin that would deviate from the ordinary regime and long-term flow were observed neither after water drawing was finished nor during the flooding of the mine and/or after it has been flooded. The impact of the drawing of groundwater and its termination on hydrogeological conditions in the Police basin is therefore negligible to zero in line with the assumed low permeability of the Permian-Carboniferous subsoil of the basin.

\section{OBSERVATIONS IN THE UPPER METUJE BASIN}

The T. G. Masaryk Water Research Institute has been taking part in the exploration of the Police basin since 1964 and has cooperated on numerous tasks especially with the Vodní zdroje enterprise, the Czech Hydrometeorological Institute and Progeo. Most processed tasks have involved solving the balance equation of the basin and specification of its components in the upper Metuje basin, in a partial experimental Bučnice basin [3] and in the whole Police basin. Continuous data series of evaluated hydrological, hydrogeological and climatological observations regarding the upper Metuje basin have been available since 1970.

The M XII outlet of the basin on the lower outskirts of the town of Teplice is used for measuring discharge and runoff in this basin. The water gauging station is a concrete weir with a sluice, the execution of which is close to a compound measuring wasteweir. Instrumental water level measurements, discharge measurements by a hydrometric propeller and discharge evaluation have been taking place there continuously since 1970. The Metuje basin up to the M XII profile comprises an area of $74.39 \mathrm{~km}^{2}$. There are also additional water gauging stations in the Metuje basin, namely the M VIII profile on the Metuje 


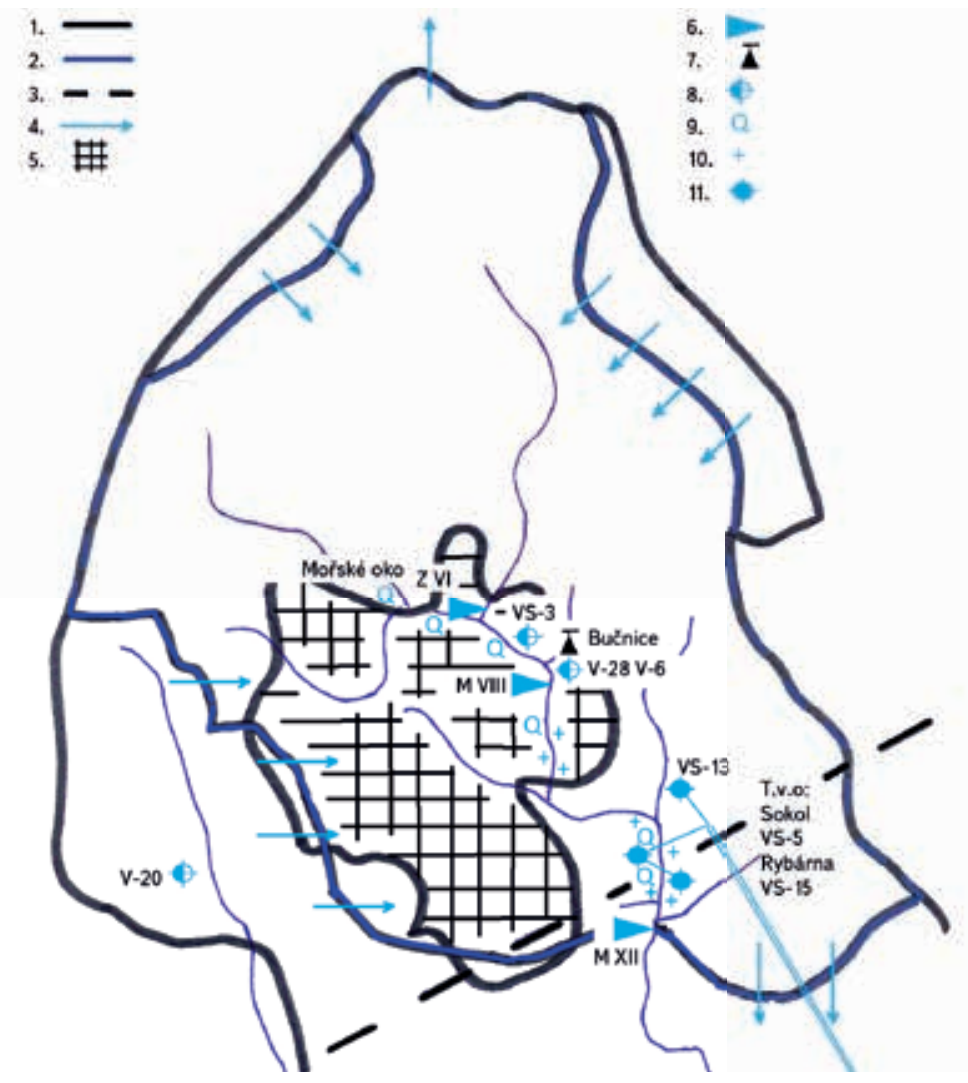

Obr. 1. Povodí horní Metuje. 1 - okraj polické pánve, 2 - orografická rozvodnice,

3 - skalský zlom, 4 - proudění podzemní vody, 5 - Skály (kolektor D),

6 - vodoměrná stanice, 7 - klimatická stanice, 8 - pozorovací vrt, 9 - pramen,

10 - výronový úsek, 11 - vodárenský vrt, teplický výronový okrsek (TVO)

\section{VYHODNOCENÍ SUCHA 2014-2019}

V letech 2014-2019 byly zaznamenány nejmenší měřené hodnoty průtoků za celou dobu pozorování na všech pozorovaných profilech a nejnižši úrovně hladiny podzemní vody ve vrtech. Na závěrném profilu M XII bylo provedeno několik hydrometrických měření průtoků nejnižších hodnot. Celkový průběh průtoku a základního odtoku (odvozeného z úrovní hladiny podzemní vody, viz níže) k profilu M XII je v grafu na obr. 2 .

Oběh vody v krajině popisuje bilanční rovnice, jež pro povodí horní Metuje obsahuje následující složky: Voda vstupuje do povodí ve formě atmosférických srážek a dále zde existuje prítok podzemní vody ze sousedních povodí. Voda ze spadlých atmosférických srážek príirozeně odchází z povodí výparem a povrchovým odtokem a především v období vegetačního klidu vsakuje do podzemních kolektorů. Větší část podzemní vody vyvěrá v povodí horní Metuje, menší množství odtéká mimo povodí. Na bilanci se také podílí změna zásoby podzemní vody. Část podzemní vody je odváděna vodárenským odběrem mimo povodí. Nádrže povrchové vody v povodí horní Metuje nejsou, objem vody v korytech toků je pro dlouhodobou bilanci zanedbatelný [3]. Jednotlivé uvedené členy bilanční rovnice jsou následně blíže specifikovány v samostatných kapitolách.

K řešení problému sucha v povodí horní Metuje byly v největší možné míre upřesněny jednotlivé položky bilanční rovnice povodí a na jejich hodnoty byl optimalizován hydrologický model Bilan. Primárními vstupy modelu Bilan jsou atmosférické srážky a teplota vzduchu, měření těchto klimatických veličin je z podstaty metody měření přesnější než u dat hydrologických. Ke zpracování dat byly použity řady měsíčních úhrnů/průměrů, především s ohledem na započítání vodárenských odběrů, které jsou v měsíčních hodnotách k dispozici.

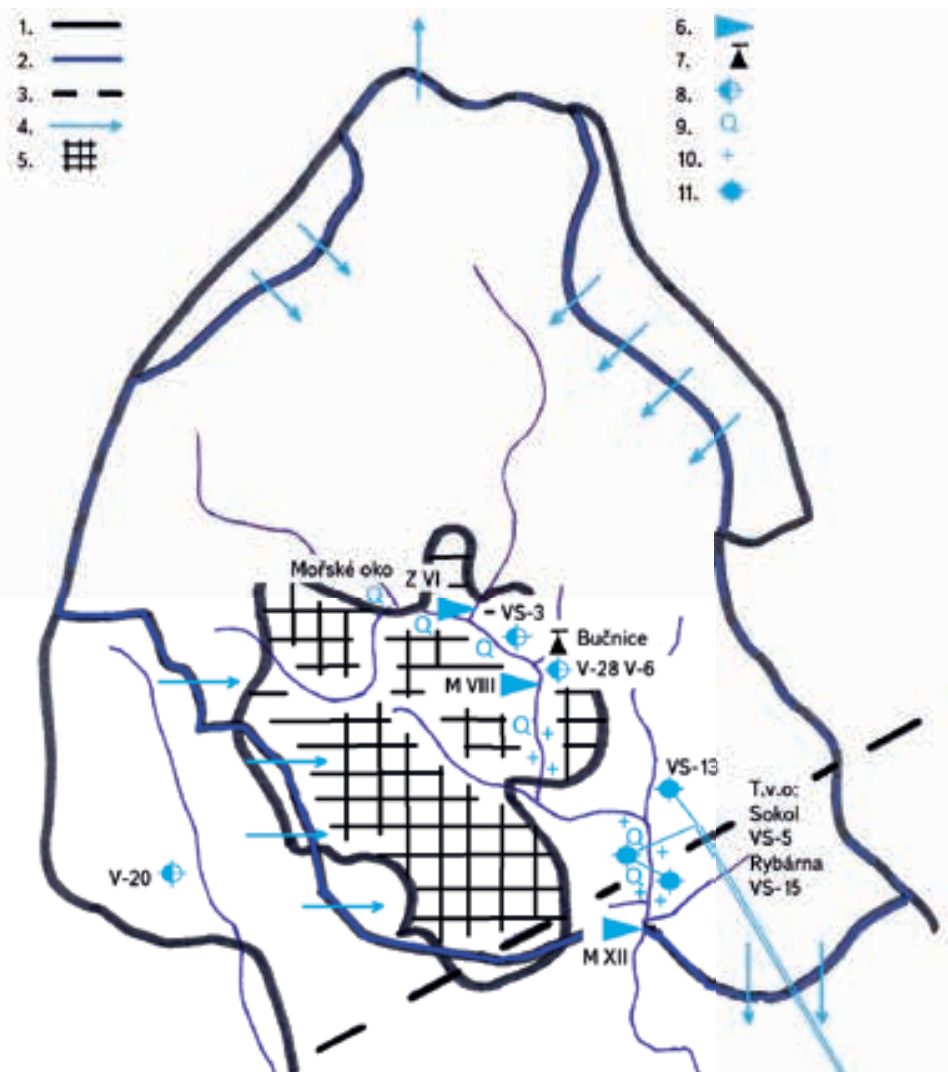

Fig. 1. Catchment area of the upper Metuje River. 1 - boundary of the Police basin, 2 - water divide line, 3 - Skalský fault, 4 - groundwater flow direction, 5 - Skály site (aquifer D), 6 - water gauging station, 7 - meteorological station, 8 - observation well, 9 - spring, 10 - outflow section, 11 - water wells, Teplice outflow zone ("T.v.o.")

River near Skalní mlýn where observations have been taking place since 1970 as well and a newer additional profile M VII (2017) below a confluence of the Metuje River and the Zdoňovský Creek. Observations at the Z VI outlet the of the Zdoňovský Creek have been taking place since 1996. Measurements performed by these stations specify runoff conditions of individual parts of the catchment area and they also specify and check measurements at the M XII outlet of the basin.

Groundwater level is monitored by three wells. Since 1972 water level has been measured in the VS-3 well. The water level in this well is the result of an interconnection of multiple aquifers, of which especially the A2 aquifer of chert layers has a significant impact. The A1/T basal aquifer has been monitored by the $\mathrm{V}-28$ well since 1990. Conditions in the Quaternary upper aquifer have been monitored by two wells located near each other, namely V-6 (since 1970) and NS, which are evaluated jointly. Groundwater level in the Northern part of the Police basin has also been monitored by observation objects of the Czech Hydrometeorological Institute. Available data have been used to specify runoff conditions.

Basic climatological observations, measurements of atmospheric precipitation and air temperature have been taking place at the Bučnice observation station since 1970. Since 1999 an automatic meteorological station has been in operation there.

Fig. 1 presents a simplified situation of the location of the upper Metuje River catchment area in the Police basin as well as the location of the observation objects. 

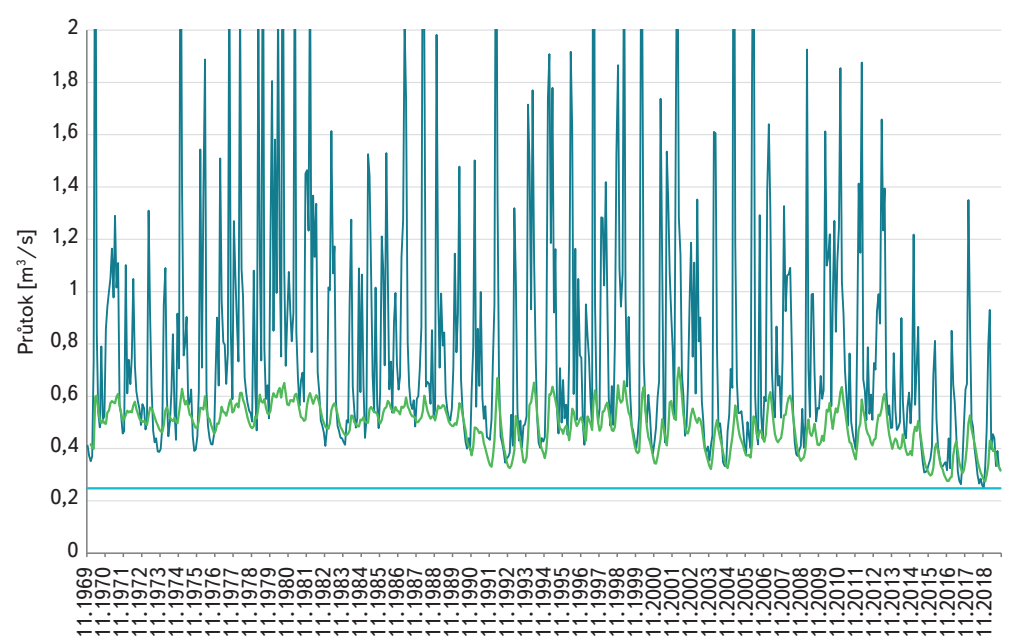

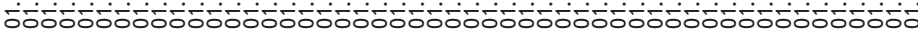

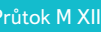

Základní podzemni odtok

Minimum XI 2018

Obr. 2. Průtok a základní odtok v profilu Metuje M XII

\section{ATMOSFÉRICKÉ SRÁŽKY}

Pro výpočet úhrnů měsičních srážek v povodí Metuje byla použita data ze srážkoměru pozorovací stanice Bučnice. Ta je umístěna přibližně ve středu povodí horní Metuje, na louce při soutoku potoka Bučnice s Metují, v nadmořské výšce 490 m n. m. Většina plochy povodí je tak ve vyšší nadmořské výšce, než v jaké jsou měřeny srážky, což bylo zohledněno navýšením srážek př̌i vyhodnocení.

Rozdíl mezi srážkami zachycenými standardním srážkoměrem ve výšce $1 \mathrm{~m}$ a srážkami měřenými na úrovni terénu byl opraven podle zjištění Klinera [3] koeficientem 1,02 pro kapalné a 1,05 pro sněhové srážky.

Úhrny srážek měřené na stanici Bučnice jsou velmi blízké srážkovým úhrnům stanoveným ČHMú pro povodí Metuje k níže položenému profilu Maršov. Za vyhodnocené období hydrologických roků 1970-2019 byl průměrný roční úhrn srážek pro stanici Bučnice 747 mm, pro Metuji po Maršov (ČHMÚ) 751 mm. Srážky od roku 1970 do roku 2019 nevykazují trend dlouhodobé změny.

\section{PŘíTOK PODZEMNÍ VODY ZE SOUSEDNÍCH POVODÍ A ODTOK PODZEMNÍ VODY MIMO POVODÍ}

Plocha sedimentů polické pánve je plošně větší než morfologické povodí horní Metuje. V křídové pánvi je také horní povodí toku Dřevíče, který opouští křídu pod obcí Janovice, plocha povodí tohoto vodního toku v polické pánvi je 11,2km². Okraje pánve (trias) na severu jsou v povodí Zadrny a Scinawky (Stěnavy). Podle zjištěných úrovní hladiny podzemní vody a z těchto hladin Uhlíkem [4] sestavené mapy hydroizopiez podzemní voda proudí vzhledem k úklonu vrstev sedimentů do centrální oblasti s říční sítí Metuje. Je tady také malá oblast (v povodí Zdoňovského potoka), kde z pánve odtéká podzemní voda severním směrem do povodí Zadrny. Na jihu povodí horní Metuje odtéká podzemní voda mimo povodí z oblasti jižně od skalského zlomu. $V$ této oblasti je větší část povodí levostranného prítoku Metuje - Bohdašínského potoka - a také malá oblast na pravé straně jejího toku. Prítok a odtok podzemní vody z oblastí mimo povodí horní Metuje je zakreslen v mapě (obr. 1). Za predpokladu, že rozdělení srážkové vody na výpar, povrchový odtok a dotaci podzemní vody jsou v prostředí pánve stejné, Ize pro prítok/odtok hodnotit rozdíl plochy území s dotací a ztrátou. Tento rozdíl je 11 km² ku prospěchu dotace ze sousedních povodí.

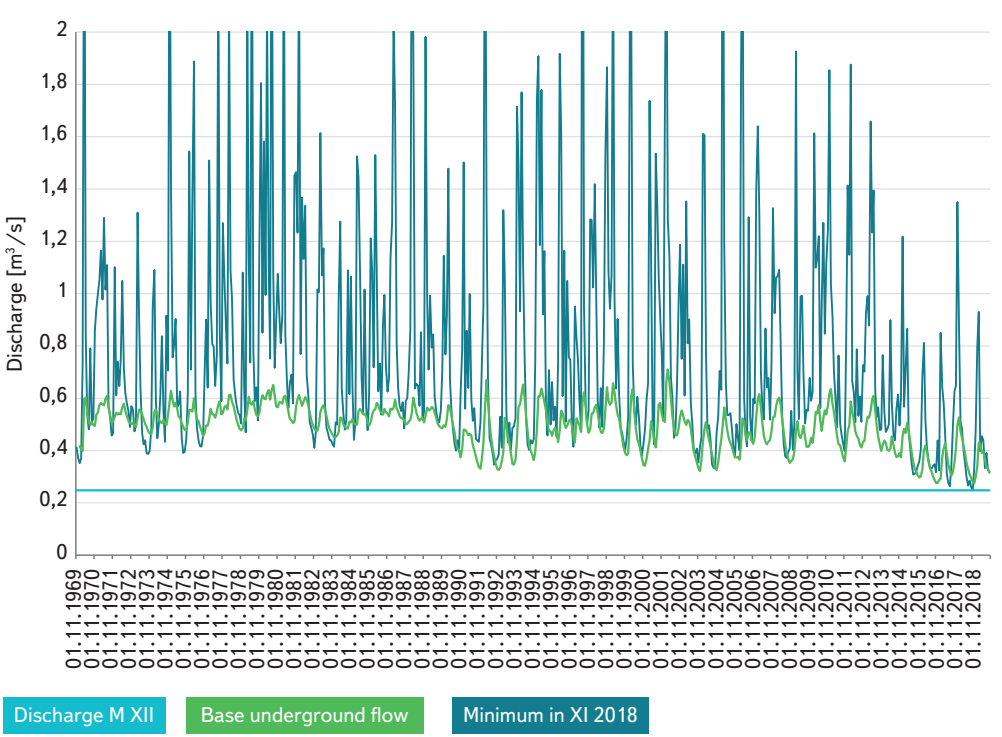

Fig. 2. Discharge and base flow in the Metuje M XII profile

\section{EVALUATION OF DROUGHT IN 2014-2019}

In 2014-2019 the lowest measured discharge rates were recorded over the whole observation period at all observed profiles as well as the lowest groundwater levels in the wells. Several hydrometric measurements of the lowest discharges were made at the M XII outlet of the basin. Fig. 2 presents total discharge and base flow (derived from groundwater levels, see below) to the M XII profile.

Water circulation in the landscape is described by a balance equation that contains the following components for the upper Metuje basin: water enters the catchment area in the form of atmospheric precipitation plus there is inflow of groundwater from neighbouring catchment areas. Water from atmospheric precipitation leaves the catchment area naturally by evaporation and surface runoff and especially in the vegetative rest period it is absorbed in underground aquifers. A larger part of groundwater springs to the surface in the upper Metuje basin and a smaller part flows away from the catchment area. A change in groundwater storage also contributes to the balance. A part of groundwater is drained away from the catchment area for water supply purposes. There are no surface water reservoirs in the upper Metuje basin and water volume in stream beds is negligible for the long-term balance [3]. Individual components of the balance equation are specified in greater detail in separate chapters.

To address the issue of drought in the upper Metuje basin, individual components of the balance equation of the catchment area have been specified as much as possible and the Bilan hydrological model has been optimised to their values. Primary inputs into the Bilan model include atmospheric precipitation and air temperature. Measurement of these climatological variables is more precise than hydrological data due to the nature of the measurement. Series of monthly totals/averages have been used for data processing, especially with regard to including water supply, which is available in monthly values.

\section{ATMOSPHERIC PRECIPITATION}

Data from a rain gauge at the Bučnice observation station have been used to calculate monthly precipitation totals in the Metuje basin. The rain gauge is located approximately in the centre of the upper Metuje basin on a meadow near the confluence of the Bučnice Creek and the Metuje River at a height of 490 metres above sea level. Most of the catchment area is thus located at 
Přibližnou hodnotu odtoku podzemní vody Ize zjistit analýzou závislosti mezi úrovní hladiny podzemní vody a odtokem v závěrném profilu povodí horní Metuje M XII (separace základního odtoku metodikou Kněžek-Kliner). Za tímto účelem byla porovnána hladina podzemní vody na konci více vybraných období poklesu ve vrtech VS-3, V-20, V-28, V-6 a vydatnosti pramene Mořské oko s odpovídajícími poklesy průtoku na profilu M XII. Pro potlačení vlivu vodárenských odběrů a prípadných dlouhodobých změn parametrů pozorovacích vrtů bylo hodnocené období rozděleno na pět desetiletých úseků. Takto získaný průběh základního odtoku podzemní vody je zobrazen na obr.2.

Prítok podzemní vody kolektory A1T a A2 z prílehlých sousedních povodí navyšuje vydatnost teplického výronového okrsku, mělké kolektory se odvodňují prameny v príslušných povodích.

Podle podílu teplického výronového okrsku na celkovém základním odtoku a velikosti plochy mimo povodí, ze které pochází tento prítok, byla ze základního odtoku dopočítána přibližná hodnota tohoto přitoku. O tento prítok podzemní vody z oblasti mimo povodí horní Metuje byl celkový odtok z povodí zmenšen

S odtokem podzemní vody mimo povodí souvisí i problematika propustnosti skalského zlomu. Skalský zlom kříží údolí Metuje $v$ dolní části města Teplice nad Metují, přesněji se zde křriži skalský zlom se zlomem polickým, který určuje v Teplicích morfologii údolí řeky. Nad a na skalském zlomu je dolní část teplického výronového okrsku, pramen Rybárna (také Pstruhárna, Prameniště, Jezírko), a úsek toku s prímou dotací podzemní vodou v korytě. S postupným získáváním znalostí o tomto zajímavém místě se ukazuje komplikovanost a členitost hydrogeologických poměrů a také se mění a různí názory na možnost proudění podzemní vody skrze či přes strukturu zlomu $[5,6]$. Rozdíl výšky hladiny podzemní vody nad a pod skalským zlomem je přibližně 40 m, nad zlomem v teplickém výronovém okrsku je piezometrická úroveň hladiny nad terénem. Podzemní voda může pronikat skrze strukturu zlomu, případně přetékat zlom kvarterní říční nivou. Odhad množství podzemní vody, jež překoná zlom, je velmi nejistý, pro bilanci pokládáme skalský zlom za nepropustný. Hodnoty průměrného dlouhodobého specifického odtoku tento předpoklad podporují. Metuje má k profilu M XII specifický odtok 11 I..-1. $\mathrm{km}^{-2}$, k profilu Hronov, který uzavírá celou polickou pánev, je také 11 I. $\mathrm{s}^{-1} \cdot \mathrm{km}^{-2}$. Sousední vodní tok Dřevíč má specifický odtok 10,4 I. . $^{-1} \mathrm{~km}^{-2}$ (z dat vodoměrných stanic ČHMú).

\section{ODTOK Z POVODÍ}

Odtok z povodí je vypočten podle průtoku v závěrném profilu Metuje M XII. Tímto měrným profilem pro jeho polohu pod dělícím skalským zlomem a koncem teplického výronového okrsku odtéká většina vody z povodí. Vliv krátkého úseku toku nad profilem M XII od konce teplického výronového okrsku, ve ztrátové oblasti pod skalským zlomem, byl zhodnocen na základě měření a odhadu na ztrátu $10 \mathrm{l} / \mathrm{s}$. Měrná křivka a měrný profil byly zkontrolovány, za dobu pozorování 1970-2019 nedošlo ke změně hydraulických parametrů. Průtok měěený touto vodoměrnou stanicí je kontrolován podle průtoku níže po toku ležící vodoměrné stanice v Maršově nad Metují, provozované ČHMú.

\section{VODÁRENSKÉ ODBĚRY ODVEDENÉ MIMO POVODÍ}

Odběratelů podzemní vody je v povodí několik, nejvýznamnější jsou Vodovody a kanalizace Náchod, a. s., jež v Teplicích nad Metují provozují soustavu čerpaných vodárenských vrtů a vodovodním prevaděčem Teplice-Bohuslavice odvádějí vodu mimo povodí. Voda spotřebovaná městem Teplice nad Metují je též odvedena z povodí horní Metuje, výtok z čistírny odpadních vod ústí do Metuje několik set metrů pod závěrným profilem M XII. K započítání množství a higher altitude than where precipitation is measured, which has been taken into account in the evaluation by increasing precipitation.

The difference between precipitation captured by a standard rain gauge at a height of $1 \mathrm{~m}$ and precipitation measured at ground level has been corrected in accordance with Kliner's findings [3] by a coefficient of 1.02 for rainfall and 1.05 for snowfall.

Precipitation totals measured at the Bučnice station are very close to precipitation totals determined by the Czech Hydrometeorological Institute for the Metuje basin up to the Maršov profile at a lower altitude. Over the evaluated period of hydrological years 1970-2019, the average annual precipitation total at the Bučnice station stood at $747 \mathrm{~mm}$ and at Metuje up to Maršov at $751 \mathrm{~mm}$ (CHMI). Precipitation between 1970 and 2019 does not show a trend of a long-term change.

\section{INFLOW OF GROUNDWATER FROM NEIGHBOURING CATCHMENT AREAS AND GROUNDWATER RUNOFF AWAY FROM THE CATCHMENT AREA}

The area of the Police basin sediments is larger than the morphological catchment area of the upper Metuje River. The upper catchment area of the Dřevíc Creek is also located in the Cretaceous basin. This watercourse leaves the Cretaceous below the municipality of Janovice and its catchment area in the Police basin amounts to $11.2 \mathrm{~km}^{2}$. The boundaries of the basin (Triassic) in the North are located in the catchment areas of the Zadrna River and the Scinawka (Stěnava) River. According to established groundwater levels and a hydroisopieze map put together by Uhlík [4] on the basis of these levels, groundwater flows to the central area where the Metuje river system is located due to a slanting of the sediment layers. There is also a small site (in the Zdoňovský Creek catchment area) where groundwater flows away from the basin in the Northern direction to the Zadrna catchment area. In the South of the upper Metuje basin groundwater flows away from the basin from a site to the South of the Skalský fault. A larger part of the catchment area of the Bohdašínský Creek, a left-bank tributary of the Metuje River, plus a small area on the rightbank side of the river are located there. The inflow and runoff of groundwater from areas outside the upper Metuje basin are marked in a map (Fig. 1). Assuming that the division of rainwater into evaporation, surface runoff and groundwater recharge is the same in the basin, the difference in the area where recharge and deficit occurs may be evaluated for inflow/runoff. This difference stands at $11 \mathrm{~km}^{2}$ in favour of recharge from neighbouring catchment areas.

An approximate value of groundwater runoff may be established by analysing the dependence between groundwater level and runoff at the M XII outlet of the upper Metuje basin (base flow has been separated by using the Kněžek - Kliner methodology). For this purpose, groundwater level has been compared at the end of multiple selected periods of decline in wells VS-3, V-20, V-28, V- 6 and abundance of the Mořské oko spring with corresponding declines in discharge at the M XII profile. The evaluated period has been broken down into five ten-year sections in order to minimise the effect of water supply and potential long-term changes in observation well parameters. Fig. 2 presents groundwater base flow that has thus been obtained.

The inflow of groundwater via the AIT and A2 aquifers from adjacent neighbouring catchment areas increases the abundance of the Teplice outflow zone. Shallow aquifers are drained by springs in the respective catchment areas.

On the basis of the contribution of the Teplice outflow zone to the total base flow and the size of the area outside the basin from which this inflow comes, the approximate value of this inflow has been calculated from base flow. Total runoff from the catchment area has been reduced by this groundwater inflow from an area outside the upper Metuje basin. 
odebrané vody byla použita data ze souborů státní vodohospodářské bilance k profilu Maršov. Velikost vodárenského odběru byla pro výpočet snížena o prů-

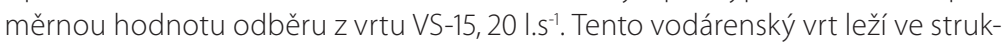
tuře skalského zlomu, úroveň hladiny podzemní vody $v$ tomto vrtu je $v$ neovlivněném stavu níže než hladina řeky [5]. Většina až všechna voda čerpaná tímto vrtem již nenáleží k bilancované oblasti severního zvodněného systému polické pánve.

Celkový odtok zadaný pro kalibraci hydrologického modelu Bilan byl opraven o velikost realizovaných odběrů podzemní vody a výměnu podzemní vody se sousedními povodími.

\section{ZTRÁTA VODY VÝPAREM}

Ztráta vody výparem, především evapotranspirací ve vegetačním období, je počítána modelem Bilan na základě teploty vzduchu a dostupného množství vody v pưdě.

Teplota vzduchu ve $2 \mathrm{~m}$ nad povrchem je př́strojově měřena meteorologickou stanicí Bučnice. Teplota má průkazně stoupající trend $0,04^{\circ} \mathrm{C}$ za rok. Průběh teploty je znázorněn na obr. 3. Pro srovnání jsou vykresleny i teploty pro povodí Metuje po Maršov nad Metují a dlouhá časová řada pro povodí Labe v Děčíně

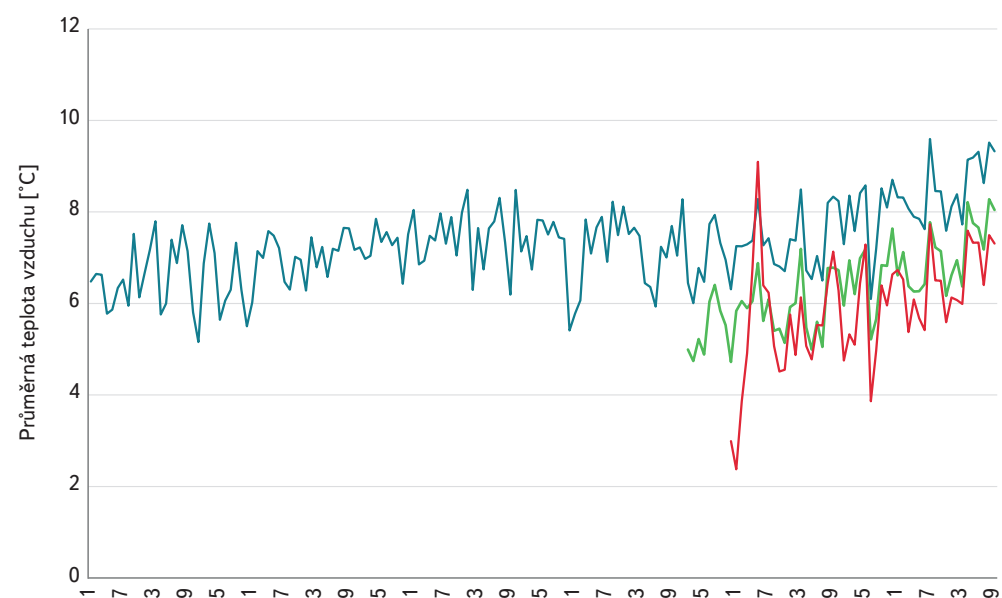

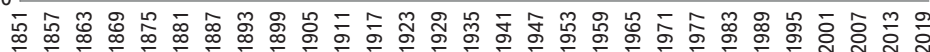

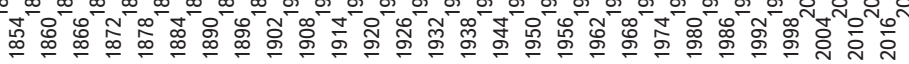

\section{Děčín} Maršov Bučnice

Obr. 3. Průměrná roční teplota vzduchu

\section{ZÁSOBA PODZEMNÍ VODY A ODTOK PODZEMNÍ VODY}

Zásoba podzemní vody a odtok podzemní vody (základní odtok) jsou výstupem programu Bilan.

\section{Aplikace modelu Bilan}

Model Bilan [7] počítá v měsíčním kroku chronologickou hydrologickou bilanci povodí či území. Vyjadřuje základní bilanční vztahy na povrchu povodí, v zóně aerace, do níž je zahrnut i vegetační kryt povodí, a v zóně podzemní vody. Jako ukazatel bilance energie, která hydrologickou bilanci významně ovlivňuje, je použita teplota vzduchu.
Groundwater runoff away from the catchment area is related to the permeability issue of the Skalský fault. The Skalský fault crosses the Metuje valley in the lower part of the town of Teplice nad Metují, or rather the Skalský fault crosses there with the Police fault, which determines the river valley morphology in Teplice. Above and at the Skalský fault there is the lower part of the Teplice outflow zone, the Rybárna spring (also known as Pstruhárna, Prameniště or Jezírko) and a section of the watercourse with a direct recharge by groundwater in the bed. As knowledge is gradually obtained about this interesting site, the complicated and varied nature of hydrogeological conditions is becoming apparent, opinions are changing and starting to differ on the possibility of groundwater flow through or across the fault structure $[5,6]$. The difference in groundwater level above and below the Skalský fault is approximately $40 \mathrm{~m}$. Above the fault in the Teplice outflow zone piezometric water level is above the ground. Groundwater may permeate through the fault structure or overflow the fault via a Quaternary fluvial meadow. An estimate of the amount of groundwater that overcomes the fault is highly uncertain and for the sake of the balance the Skalský fault is considered impermeable. Values of the average long-term specific runoff support this assumption. Specific runoff of the Metuje River up to the M XII profile stands at $111 . \mathrm{s}^{-1} . \mathrm{km}^{-2}$ and up to the Hronov profile that closes the whole Police basin it also stands at $111 . \mathrm{s}^{-1} \cdot \mathrm{km}^{-2}$. Specific runoff of the neighbouring Dřevíč Creek amounts to $10.41 . \mathrm{s}^{-1} \cdot \mathrm{km}^{-2}$ (data obtained from water gauging stations of the Czech Hydrometeorological Institute).

\section{RUNOFF FROM THE CATCHMENT AREA}

Runoff from the catchment area has been calculated according to discharge in the M XII outflow of the Metuje basin. Most water flows away from the catchment area through this gauging station due to its location below the dividing Skalský fault and at the end of the Teplice outflow zone. The impact of the short section of the watercourse above the M XII profile from the end of the Teplice outflow zone in the deficit area below the Skalský fault has been evaluated on the basis of measurements and estimated deficit of $10 \mathrm{l} / \mathrm{s}$. The rating curve and the gauging station have been checked and it has been established that hydraulic parameters were not changed over the observation period of 1970-2019. Discharge measured by this water gauging station is checked on the basis of a discharge at a water gauging station in Maršov nad Metuji that is located downstream and operated by the Czech Hydrometeorological Institute.

\section{WATER SUPPLY TAKEN AWAY FROM THE CATCHMENT AREA}

There are several groundwater users in the catchment area, the most important being Vodovody a kanalizace Náchod, a. S., which operates a system of water wells in Teplice nad Metuji and takes water away from the catchment area by the Teplice-Bohuslavice water transfer. Water used by the town of Teplice nad Metují is also drained away from the upper Metuje basin. An outflow from a waste water treatment station flows into the Metuje River several hundred metres below the M XII outlet of the basin. Data from the national water management balance files regarding the Maršov profile have been used in order to calculate the amount of drawn water. The water supply has been reduced for calculation purposes by the average value of water drawn from well VS-15, 201. . $^{-1}$. This water well lies in the Skalský fault structure and groundwater level in this well is lower than the river level without any impact [5]. A majority up to all the water drawn from this well does not belong to the assessed area of the Northern aquiferous system of the Police basin.

The total runoff input for calibrating the Bilan hydrological model has been adjusted by the amount of effected groundwater supply and groundwater exchange with the neighbouring catchment areas. 
Vstupními hodnotami modelu jsou časové řady měsíčních výšek srážek v povodí a řady průměrných měsíčních teplot vzduchu. Při odhadu parametrů modelu se zadávají řady měsičních odtokových výšek v závěrovém profilu povodí.

Výpočtem byly získány potenciální evapotranspirace, územní výpar, infiltrace do zóny aerace, průsak touto zónou do podzemních vod, zásoba vody ve sněhu, zásoba vody v pưdě a zásoba podzemní vody. Celkový odtok je modelován jako součet tři složek: dvě složky prímého odtoku (zahrnující i hypodermický odtok) a základní odtok. Základní odtok Ize ztotožnit s drenáží podzemní vody do říční sítě po závěrný profil.

Model má osm volných parametrů. Pro jejich odhad se v profilech s vodoměrným pozorováním používá optimalizační program, který hledá parametry tak, aby bylo dosaženo minimální hodnoty zvoleného kritéria shody modelovaného odtoku s pozorovanými daty.

Při kalibraci modelu byly pro data z 90. let patrné rozdíly mezi modelovaným a měřeným odtokem. Podrobnější kontrolou podle zprávy Uhlíka [4] byly zjištěny nesrovnalosti dostupných hodnot odběrů. Pro kalibraci byl úsek nejistých dat vynechán, nebyly použity hydrologické roky 1990-1999. Úroveň hladiny podzemní vody byla na začátku a konci vynechaného úseku podobná.

Ke kalibrování modelu Bilan bylo třeba zvýšit atmosférické srážky koeficientem 1,105, který zohledňuje vliv nadmořské výšky srážkoměrné stanice Bučnice.

Na obr. 4 je vykreslen průběh pozorovaného odtoku z povodí (R) a modelovaného odtoku (RM), pro lepší přehlednost jsou zobrazeny 3měsíční klouzavé průměry.

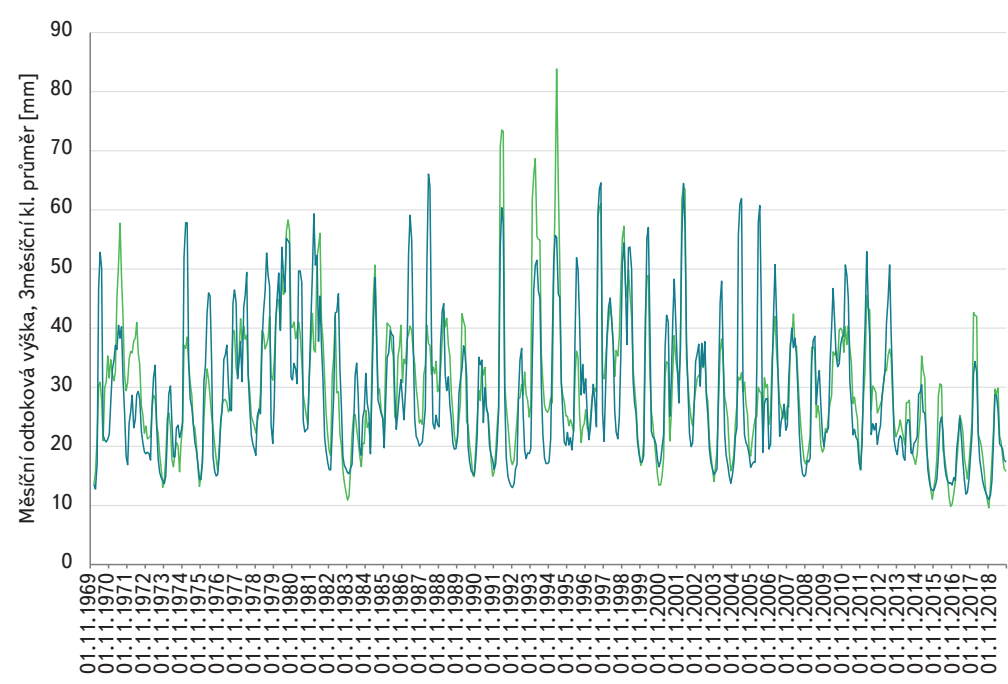

RM $R$

Obr. 4. Pozorovaný (R) a modelovaný odtok (RM), 3měsiční klouzavé průměry

Z porovnání hodnot skutečného a modelovaného odtoku jsou patrné rozdíly při větších hodnotách odtoku. Tyto Ize vysvětlit nerovnoměrným rozložením srážek přívalových deštư na ploše povodí. Také se zde projevuje nepřesnost samotného měření hladiny při vysokých stavech a rychlých změnách a to, že měrná křivka průtoků je pro velké průtoky odvozena pouze hydraulickým výpočtem. V grafu na obr. 4 jsou zachyceny znatelné nepřesnosti hodnot odběrů vody v 90. letech. Celkově se shoda měřeného odtoku a modelovaného odtoku s časem zlepšuje.

\section{WATER LOSS CAUSED BY EVAPORATION}

Water loss caused by evaporation, in particular evapotranspiration in the vegetation period, has been calculated by the Bilan model based on air temperature and available amount of water in the soil.

The Bučnice meteorological station measures air temperature instrumentally $2 \mathrm{~m}$ above the ground. The temperature shows a demonstrably increasing trend of $0.04^{\circ} \mathrm{C} /$ year. Fig. 3 presents the temperature over time. For the sake of comparison, temperatures in the Metuje basin up to Maršov nad Metují and a long time series in the Labe basin in Děčín are also presented.

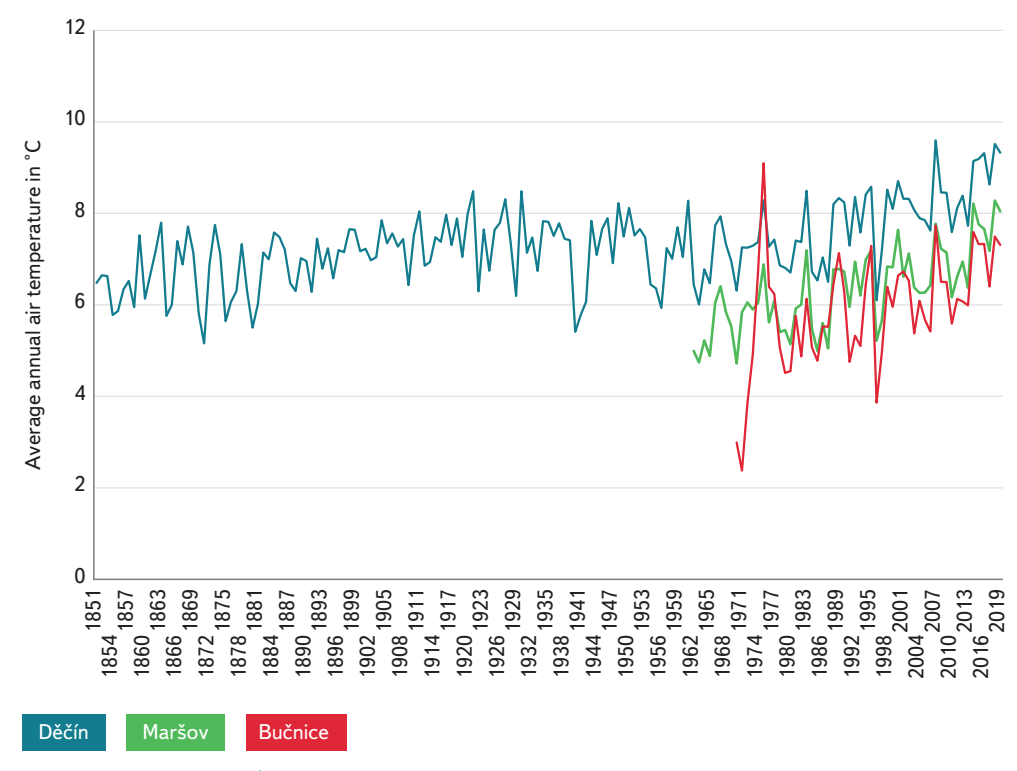

Fig. 3. Average annual air temperature

\section{GROUNDWATER STORAGE AND RUNOFF}

The Bilan programme yields groundwater storage and runoff (base flow). Out of the measured data, groundwater levels in monitoring wells document the development of groundwater storage over time.

\section{Application of the Bilan model}

The Bilan model [7] uses the monthly time step to calculate chronological hydrological balance of a catchment area or of a given area. It expresses basic balance relationships on the surface of the catchment area, in the aeration zone that also includes the vegetation cover of the catchment area and in the groundwater zone. Air temperature has been used as an indicator of energy balance, which has a significant impact on hydrological balance.

Input values of the model include time series of monthly precipitation in the catchment area and series of average monthly air temperatures. When the model parameters are estimated, series of monthly runoff heights at the outlet of the basin are put in.

The calculation has provided potential evapotranspiration, actual evaporation, infiltration into the aeration zone, seepage through this zone into groundwater, water storage in snow, water storage in the soil and groundwater storage. Total runoff is modelled as a sum of three components: two components of direct runoff (that also includes hypodermic runoff) and base flow. Base flow may be identified with groundwater drainage into the river system up to the outlet of the basin. 
Tab. 2. Měsični prưměry veličin hydrologické bilance z obdobi 1970-2019 a z obdobi 2014-2019 ve variantách pozorovaných teplot a teplot vzduchu bez rostoucího trendu

\begin{tabular}{|c|c|c|c|c|c|c|}
\hline \multirow[b]{2}{*}{ Měsíční hodnoty } & & \multicolumn{2}{|c|}{ Teplota měřená } & \multicolumn{2}{|c|}{ Teplota bez trendu } & \multirow{2}{*}{$\begin{array}{l}\text { Změna } \\
\text { 2014-2019 }\end{array}$} \\
\hline & & 1970-2019 & 2014-2019 & 1970-2019 & $2014-2019$ & \\
\hline Atmosférické srážky [mm] & $P$ & 69,1 & 60,4 & 69,2 & 60,6 & 0,2 \\
\hline Odtok modelovaný [mm] & RM & 29,7 & 20,8 & 32,0 & 24,5 & 3,7 \\
\hline Základní odtok [mm] & $\mathrm{BF}$ & 20,7 & 14,5 & 22,9 & 18,3 & 3,7 \\
\hline Potenciální evapotranspirace [mm] & PET & 42,1 & 45,6 & 39,0 & 39,8 & $-5,8$ \\
\hline Evapotranspirace [mm] & ET & 39,4 & 40,1 & 37,0 & 36,5 & $-3,7$ \\
\hline Průměrná teplota vzduchu $\left[{ }^{\circ} \mathrm{C}\right]$ & $\mathrm{T}$ & 5,9 & 7,2 & 4,9 & 5,3 & $-1,9$ \\
\hline
\end{tabular}

\section{Zásoba podzemní vody [mm]}

\begin{tabular}{|c|c|c|c|c|}
\hline K 31. 10. 2013 & GS & 132,3 & 166,8 & 34,5 \\
\hline K 31. 10. 2019 & GS & 93,6 & 139,1 & 45,6 \\
\hline Změna & & 38,7 & 27,6 & $-11,1$ \\
\hline Měsíčně & & 0,5 & 0,4 & $-0,2$ \\
\hline
\end{tabular}

Tab. 3. Celkový vliv zvyšování teploty vzduchu

\begin{tabular}{|c|c|c|c|c|c|c|}
\hline & & & \multicolumn{2}{|c|}{ Měsíční průměrný úhrn [mm] } & \multicolumn{2}{|c|}{ Měsíční trend [mm] } \\
\hline & & & T real & T kor & T real & T kor \\
\hline \multirow[t]{2}{*}{ Měření } & Atmosférické srážky & $P$ & 69,1 & 69,2 & $-0,004$ & $-0,0037$ \\
\hline & Měřený odtok & $\mathrm{R}$ & 29,1 & & $-0,01$ & \\
\hline \multirow[t]{6}{*}{ Bilan } & Modelovaný odtok & RM & 29,7 & 32,0 & $-0,01$ & $-0,002$ \\
\hline & Základní odtok & BF & 20,7 & 22,9 & $-0,007$ & $-0,0001$ \\
\hline & Zásoba podzemní vody & GS & 171,8 & 190,1 & $-0,064$ & $-0,004$ \\
\hline & Potenciální evapotranspirace & PET & 42,1 & 39,0 & 0,014 & 0,003 \\
\hline & Evapotranspirace & ET & 39,4 & 37,0 & 0,009 & 0,002 \\
\hline & Teplota $\left[{ }^{\circ} \mathrm{C}\right]$ (měsíční průměr) & $\mathrm{T}$ & 5,9 & 4,9 & 0,004 & 0 \\
\hline
\end{tabular}

\section{Určení vlivu zvyšování teploty vzduchu na odtok}

K posouzení podílu vlivu poklesu atmosférických srážek a nárůstu teploty vzduchu byl proveden výpočet odtoku s upravenou teplotou vzduchu, při použití měřených úhrnů srážek a původních parametrů nastavení kalibrace modelu. Měřené hodnoty teploty vzduchu byly pro toto vyhodnocení modelem Bilan v období 1970-2019 upraveny na nulový trend zvyšování teploty.

Porovnání výstupů modelu Bilan pro období sucha 2014-2019 s celým sledovaným obdobím 1970-2019 a porovnání pro modelovou variantu bez zvýšení teploty jsou v tab. 2.

V období 2014-2019 byl průměrný modelovaný měsíční odtok RM o 8,9mm menší než průměrný měsiční odtok za celé období pozorování 1970-2019. Tento pokles odpovídá poklesu průměrných měsíčních srážek P o 8,7 mm.

Ve vztahu k průměrným teplotám za celé období 1970-2019 byly teploty v období sucha 2014-2019 nadprůměrné, resp. odpovídající stoupajícímu trendu teploty.
The model has eight free parameters. To estimate them, water-measurement observation profiles use an optimisation programme that seeks parameters so as to reach a minimum value of the selected criterion for matching modelled runoff with observed data.

When the model was calibrated, there were apparent differences in data from the 1990s regarding modelled and measured runoff. An in-depth examination in accordance with Uhlík's report [4] has established discrepancies of available water supply values. For the purposes of calibration, the section of uncertain data was omitted and hydrological years 1990-1999 were not used. Groundwater level at the beginning and at the end of the omitted section was similar.

So as to calibrate the Bilan model, atmospheric precipitation has had to be increased by a coefficient of 1.105, which takes into account the impact of the altitude of the Bučnice rain gauging station. 
Podíl dlouhodobého zvýšení teploty na snížení odtoku v důsledku růstu výparu je významný. Pokud by ke zvýšení teploty nedocházelo, pak by výpar za období 2014-2019 byl podprůměrný a celkový rozdíl ztráty výparem by byl menší o 3,7 mm měsíčně. Tento deficit výparu by se projevil odpovídajícím zvýšením hodnoty základního odtoku BF a celkového odtoku RM.

Složka základního odtoku z klesající zásoby podzemní vody není príliš významná. Celkový pokles zásoby podzemní vody za období od začátku roku 2014 do konce roku 2019 byl 38,7 mm. Pro tento pokles odpovídá pokles objemu podzemní vody o 2,88 mil. m³. Porovnání dlouhodobých bilancí povodí horní Metuje pro celé pozorované období 1970-2019 je v tab. 3.

Atmosférické srážky za celé sledované období vykazují mírný pokles, ten však není, na rozdíl od růstu teploty, trvalého rázu. V období 1970-2013 před začátkem sucha vykazoval měsiční srážkový úhrn růst 0,009 mm. Při vyhodnocení sledovaného období po dekádách ve třech dekádách srážky stoupají, ve dvou dekádách klesají, zatímco vzestup teploty vzduchu nastal ve všech dekádách.

Vliv navýšení výparu a odpovídajícího poklesu odtoku v důsledku oteplení vzduchu je patrný, porovnáním trendů Ize približně určit vztah poklesu odtoku o 2,5 mm/měsíc při zvýšení teploty o $1^{\circ} \mathrm{C}$.

Dlouhodobý trend poklesu základního odtoku v důsledku stoupajícího podílu výparu je 0,007 mm/měsíc (při nezapočitání sucha 2014-2019 a chladného roku 1971 na začátku pozorování je trend 0,006 mm/měsíc, v období 1972-2013). Nižší hodnotě poklesu odtoku 0,006 mm/měsíc odpovídá trend poklesu průtoku v profilu M XII 2 l/s/rok. Hodnota základního odtoku je významná z hlediska vodárenských odběrů. V období sucha 2014-2019 zůstal po celou dobu sucha $\checkmark$ teplickém výronovém okrsku zachován odtok podzemní vody. Nejmenší změřená hodnota vydatnosti teplického výronového okrsku byla $150 \mathrm{l} / \mathrm{s}$, nejmenší dopočítaná kolem $100 \mathrm{I} / \mathrm{s}$. Na celkovém základním odtoku z povodí horní Metuje se v suchých obdobích teplický výronový okrsek podílí jednou polovinou. Pokud bude pokles odtoku pokračovat, v budoucnu nastanou problémy s množstvím povrchové vody. $V$ prípadě většího poklesu nebo zániku přirozeného odtoku v teplickém výronovém okrsku a změny jeho funkce z dotační na ztrátovou mohou vzniknout také problémy s kvalitou podzemní vody v blízkosti vodárenských odběrů.

\section{ZÁVĚR}

Primární príčinou sucha v období 2014-2019 v povodí horní Metuje byl pokles atmosférických průměrných měsičních srážek o 8,6 mm oproti dlouhodobému průměru. Měsiční průměrný úhrn srážek byl v uvedeném období sucha $60 \mathrm{~mm}$ měsíčně, z těchto se $40 \mathrm{~mm}$ odpařilo a $21 \mathrm{~mm}$ vody z povodí odteklo nebo bylo odebráno vodárenskými odběry ( 1 mm odteklé vody je z klesající zásoby podzemní vody). Výrazný je vliv dlouhodobého oteplování vzduchu. Pokud by k oteplování nedocházelo, odpařilo by se podle modelové simulace měsíčně jen $36 \mathrm{~mm}$ a hodnota (základního) měsíčního odtoku by byla o 4 mm větší. Tomuto nárůstu odpovídá zvýšení průtoku na profilu M XII o $110 \mathrm{I} . \mathrm{s}^{-1}$.

Poklesem odtoku z povodí se oteplování projevuje dlouhodobě, nikoli pouze v extrémní periodě 2014-2019. Opatření ke zmírnění tohoto nepř́znivého trendu mohou zmenšit výpar a povrchový odtok ve prospěch dotace zásoby podzemní vody. Tím dojde ke zvětšení základního odtoku v říční síti. Dobrými opatřeními v krajině jsou vhodně situovaná jezírka a hluboké tůně, které umožní akumulaci vody a především její vsakování do vod podzemních. Naopak mokřady a mělké nádrže v drenážních oblastech mohou vzhledem k podpoře výparu mít účinek spíše negativní. Úpravy v krajině je proto vhodné odborně posoudit z hydrologického a hydrogeologického pohledu.
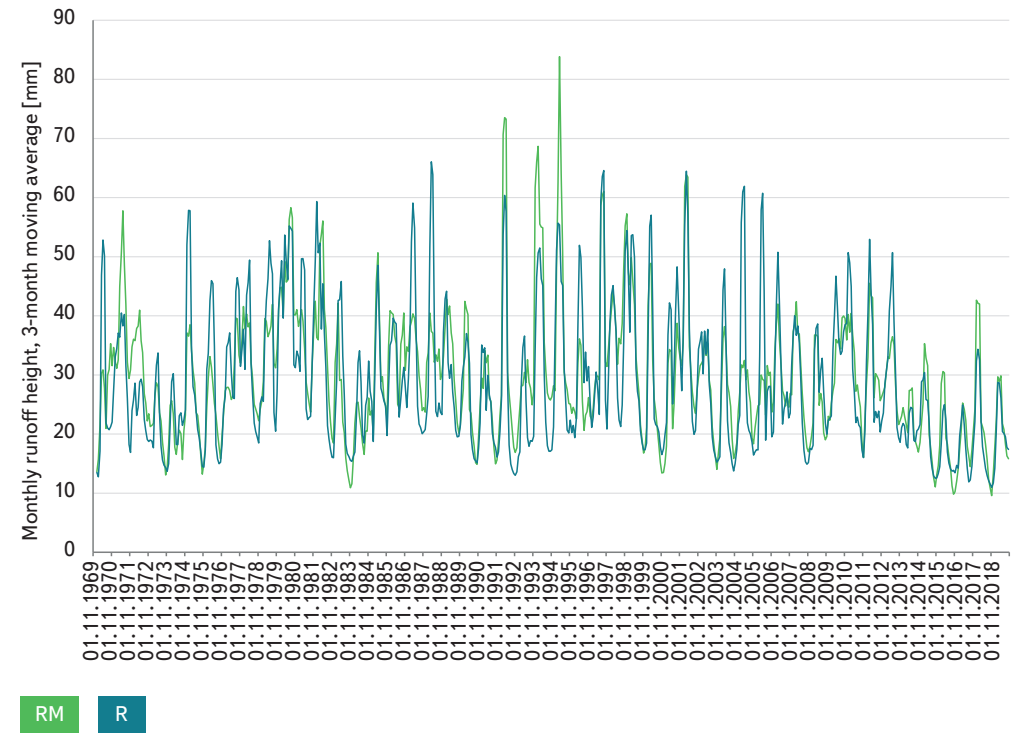

Fig. 4. Observed runoff (R) and modelled runoff (RM), 3-month moving averages

Fig. 4 shows observed runoff (R) from the catchment area and modelled runoff (RM). Three-month moving averages are presented for the sake of clarity.

An observation of the values of actual and modelled runoff shows differences in higher runoff values. These differences may be explained by uneven distribution of torrential rainfall across the catchment area. Inaccuracy of the measurement of water level in high water level conditions and fast changes is also apparent as well as the fact that the discharge rating curve for high discharges is derived only by a hydraulic calculation. A chart in Fig. 4 captures noticeable inaccuracies of water supply values in the 1990s. Overall, the match between measured runoff and modelled runoff has improved over time.

\section{DETERMINING THE IMPACT OF INCREASING AIR TEMPERATURE ON RUNOFF}

A calculation of runoff with adjusted air temperature has been made, using measured precipitation totals and the original model calibration parameters in order to assess the contribution of the impact of a decrease in atmospheric precipitation and an increase in air temperature. Measured air temperatures in the period of 1970-2019 have been adjusted for a zero trend of temperature increase for the purpose of this evaluation by the Bilan model.

Tab. 2 presents a comparison of outputs of the Bilan model for the drought period of 2014-2019 with the whole observation period of 1970-2019 and a comparison for the model variant without an increase in temperature.

In 2014-2019 the average modelled monthly runoff (RM) was by $8.9 \mathrm{~mm}$ smaller than the average monthly runoff over the whole observation period of 1970-2019. This decline corresponds with the decrease in average monthly precipitation P by $8.7 \mathrm{~mm}$.

In relation to average temperatures over the whole period of 1970-2019, temperatures in the drought period of 2014-2019 were above average or rather in line with the rising temperature trend.

The contribution of the long-term temperature rise to a decline in runoff as a result of an increase in evaporation is significant. If temperature had not increased, evaporation over the period of 2014-2019 would have been below average and the total difference in a loss caused by evaporation would have been by $3.7 \mathrm{~mm} / \mathrm{month}$ smaller. This evaporation deficit would have manifested itself by a corresponding increase in the value of base flow (BF) and total runoff (RM). 
Tab. 2. Monthly averages of hydrological balance quantities from the period of 1970-2019 and from the period of 2014-2019, in a variant of observed air temperatures and a variant of air temperatures without an increasing trend

\begin{tabular}{|c|c|c|c|c|c|c|}
\hline \multirow[b]{2}{*}{ Monthly values } & \multirow[b]{2}{*}{ Quantity } & \multicolumn{2}{|c|}{ Measured temperature } & \multicolumn{2}{|c|}{$\begin{array}{l}\text { Temperature without } \\
\text { an increasing trend }\end{array}$} & \multirow{2}{*}{$\begin{array}{l}\text { Change } \\
2014-2019\end{array}$} \\
\hline & & 1970-2019 & 2014-2019 & 1970-2019 & 2014-2019 & \\
\hline Atmospheric precipitation [mm] & $P$ & 69.1 & 60.4 & 69.2 & 60.6 & 0.2 \\
\hline Modelled runoff [mm] & RM & 29.7 & 20.8 & 32.0 & 24.5 & 3.7 \\
\hline Base flow $[\mathrm{mm}]$ & $\mathrm{BF}$ & 20.7 & 14.5 & 22.9 & 18.3 & 3.7 \\
\hline Potential evapotranspiration [mm] & PET & 42.1 & 45.6 & 39.0 & 39.8 & -5.8 \\
\hline Evapotranspiration [mm] & ET & 39.4 & 40.1 & 37.0 & 36.5 & -3.7 \\
\hline Average air temperature $\left[{ }^{\circ} \mathrm{C}\right]$ & $\mathrm{T}$ & 5.9 & 7.2 & 4.9 & 5.3 & -1.9 \\
\hline \multicolumn{7}{|l|}{ Groundwater storage [mm] } \\
\hline As at 31/10/2013 & GS & & 132.3 & & 166.8 & 34.5 \\
\hline As at 31/10/2019 & GS & & 93.6 & & 139.1 & 45.6 \\
\hline Change & & & 38.7 & & 27.6 & -11.1 \\
\hline Per month & & & 0.5 & & 0.4 & -0.2 \\
\hline
\end{tabular}

Tab. 3. Overall effect of rising air temperature

\begin{tabular}{|c|c|c|c|c|c|c|}
\hline & & & \multicolumn{2}{|c|}{ Average monthly total $[\mathrm{mm}]$} & \multicolumn{2}{|c|}{ Monthly trend [mm] } \\
\hline & & & T real & T cor. & T real & T cor. \\
\hline \multirow[t]{2}{*}{ Measurement } & Atmospheric precipitation & $P$ & 69.1 & 69.2 & -0.004 & -0.0037 \\
\hline & Measured runoff & $\mathrm{R}$ & 29.1 & & -0.01 & \\
\hline \multirow[t]{6}{*}{ Bilan } & Modelled runoff & RM & 29.7 & 32.0 & -0.01 & -0.002 \\
\hline & Base flow & $\mathrm{BF}$ & 20.7 & 22.9 & -0.007 & -0.0001 \\
\hline & Groundwater storage & GS & 171.8 & 190.1 & -0.064 & -0.004 \\
\hline & Potential evapotranspiration & PET & 42.1 & 39.0 & 0.014 & 0.003 \\
\hline & Evapotranspiration & ET & 39.4 & 37.0 & 0.009 & 0.002 \\
\hline & Temperature $\left[{ }^{\circ} \mathrm{C}\right]$ & $\mathrm{T}$ & 5.9 & 4.9 & 0.004 & 0 \\
\hline
\end{tabular}

\section{Literatura}

[1] SVOBODA, M. Hydrologická bilance povodi se zaměřením k využití podzemnich vod. Praha: Výzkumný ústav vodohospodářský T. G. Masaryka, 1969

[2] HYNIE, O. Zajištění vodních zdrojů skupinového vodovodu pro Hradec Králové a okolí v Polické kř́dové pánvi. Palivo a voda. 1949, roč. 29, č. 7

[3] KLINER, K. Rozdělení srážek na evapotranspiraci a tvorbu podzemnich vod metodou komplexní bilance povodí. Praha: Výzkumný ústav vodohospodářský T. G. Masaryka, 1971

[4] UHL[KK, J. Analýza klimatické změny v povodi Horní Metuje po Hronov. Roztoky u Prahy: PROGEO, 2008

\section{[5] KNĚŽEK, V. Závěrečné zhodnocení Pitná voda. Praha: Vodní zdroje, 1975}

[6] KRÁSNÝ, J. Optimalizace využivání a ochrany podzemnich vod s ohledem na ostatni složky životního prostředí: Polická pánev. Praha: Ústav hydrogeologie, inženýrské geologie a užité geofyziky Prírodovědecké fakulty Univerzity Karlovy, 1995

[7] VIZINA, A., HORÁČEK, S., HANEL, M. Nové možnosti modelu Bilan. Vodohospodářské technicko-ekonomické informace. 2015, roč. 57 (4-5), s. 7-10
The base flow component is not very significant in decreasing groundwater storage. The overall decrease in groundwater storage over the period from the beginning of 2014 until the end of 2019 amounted to $38.7 \mathrm{~mm}$. A decrease in the volume of groundwater by 2.88 mil. $\mathrm{m}^{3}$ corresponds with this decline. Tab. 3 presents a comparison of long-term balances of the upper Metuje basin over the whole observation period of 1970-2019.

Atmospheric precipitation over the whole monitored period shows a moderate decline, which is however not permanent in nature as opposed to the rising temperature. In the period of 1970-2013 before the drought started, the monthly precipitation total grew by $0.009 \mathrm{~mm}$. When the observation period is evaluated by decades, it may be noted that precipitation saw a rise in three decades and a decline in two decades whereas air temperature increased in all the decades. 
Autor

\section{Jan Kašpárek}

凶jan.kasparek@vuv.cz

ORCID: 0000-0002-5391-1540a

Výzkumný ústav vodohospodářský T. G. Masaryka

Přispěvek prošel lektorským řízením.

DOI: 10.46555/VTEI.2021.05.001
There is a clear impact of an increase in evaporation and a corresponding decline in runoff as a result of rising air temperature. When the trends are compared, it may be determined that runoff declines by $2.5 \mathrm{~mm}$ when temperature increases by $1^{\circ} \mathrm{C}$.

The long-term trend of a decline in base flow as a result of a rising contribution of evaporation stands at $0.007 \mathrm{~mm} / \mathrm{month}$ (if the drought of 2014-2019 and the cold year 1971 at the beginning of the observation are not included, the trend in the period of $1972-2013$ stands at $0.006 \mathrm{~mm} / \mathrm{month})$. The lower value of a decline in runoff of $0.006 \mathrm{~mm} / \mathrm{month}$ corresponds with a trend of a decline in discharge at the M XII profile of $2 \mathrm{l} / \mathrm{s} /$ year. The base flow value is significant with regard to water supply. Groundwater runoff was maintained in the Teplice outflow zone throughout the whole drought period of 2014-2019. The lowest measured value of abundance of the Teplice outflow zone stood at $150 \mathrm{I} / \mathrm{s}$ and the smallest calculated value was around $100 \mathrm{l} / \mathrm{s}$. In periods of drought, the Teplice outflow zone contributes to the total base flow from the upper Metuje basin by one half. If runoff continues to decrease, problems will occur in the future with the amount of surface water. If there is a larger decline or if the natural runoff in the Teplice outflow zone ceases to exist and its function changes from a recharge to a deficit one, problems may also arise with groundwater quality in the vicinity of the water supply sites.

\section{CONCLUSION}

The primary cause of drought in the period of 2014-2019 was a decrease in average monthly atmospheric precipitation by $8.6 \mathrm{~mm} / \mathrm{month}$ in the upper Metuje basin in comparison with the long-term average. The monthly average precipitation total in the period of drought stood at $60 \mathrm{~mm} / \mathrm{month}$, of which $40 \mathrm{~mm}$ was evaporated and $21 \mathrm{~mm}$ of water flew away from the catchment area or was used for water supply $(1 \mathrm{~mm}$ of the flown-away water comes from the decreasing groundwater storage). The impact of a long-term increase in air temperature is significant. If warming had not been taking place, only $36 \mathrm{~mm} / \mathrm{month}$ would have evaporated according to a model simulation and the value of the (base) monthly runoff would have been by $4 \mathrm{~mm}$ larger. This increase corresponds with an increase in discharge at the M XII profile by $110 \mathrm{l} . \mathrm{s}^{-1}$.

Warming has been manifesting itself by a decline in runoff from the catchment area long-term, not only in the extreme period of 2014-2019. Measures aimed at mitigating this unfavourable trend may lower evaporation and surface runoff in favour of groundwater recharge. This would increase base flow in the river system. Positive measures in the landscape include appropriately located ponds and deep pools that enable water accumulation and especially its seepage into groundwater. On the contrary, wetlands and shallow reservoirs in drainage areas may have a rather negative effect since they support evaporation. Measures in the landscape should therefore be expertly assessed from a hydrological and hydrogeological perspective. 